\title{
The Design of Children's Educational Game Interface: Review of the Literature
}

\author{
Yope Bintang Anugerah $^{1}$ and Cucuk Wawan Budiyanto ${ }^{1}$ \\ ${ }^{1}$ Information Technology Education, Universitas Sebelas Maret, Jl. Jend. Ahmad Yani 200A Pabelan, \\ Kartasura, Sukoharjo, Indonesia. \\ Email: yopebintang@student.uns.ac.id
}

\begin{abstract}
Alongside the development of graphical resolution of computer displays, computer games become a prominent media for educational and recreational purposes. The visual in video games is believed to have a major role in learning, as the learning happens with visual description. Although computer games have been realized as a tool for teaching and learning of complex conceptual subjects, the way how visual design delivers wisdom was remain underexplored. This paper reviews the recent trend of children educational games to obtain an understanding of the multifaceted advantages of visual imageries of computer games. A systematic review over the pool of 200 papers from two established journals in education was conducted. The patterns of how visual design contributes to learning were investigated. The insight from the reviewed papers, subsequently, was analyzed to construct an elaboration on the use of visual computer game design to improve the learning experience.
\end{abstract}

Keywords: game-based learning; game visual design; visual learning, literature review.

\section{INTRODUCTION}

Alongside the development of graphical resolution of computer displays, computer games become a prominent media for educational and recreational purposes. Game-based learning system helps students to learn in a fun way, especially with computer games as a training material in an education activity [1]. It is believed that educational games are effective for their ability to motivate children to actively engage in a learning activity as part of playing the game [2].

The important aspect including imagination, fantasy, and experience gained by playing games [3]. Singaporean teachers highlighted that although the Ministry of Education supported the game-based learning, it made no specific policies regarding game adoption, which led to a lack of instructional game materials, inadequate training for teachers and inadequate administrative support for innovation [4]. This paper will discuss how educational games can help students improve their ability depends on how they react the graphical design on the games. 
Notwithstanding the vast literature on graphic design for educational games, there seems likely a lack of explanation on how the graphic design on education games would affect kids' learning ability. This condition would likely leave practitioners and academic without clear guidance on how to operationalize the graphic design on educational games for kids' learning in real life. This review examines the published works in few established journals of interactive learning research. A systematic literature review procedure was conducted upon twenty journals published between 2013 and 2017. Also, to obtaining a granular elaboration about the matter, a framework to operationalize the educational games in interactive learning especially in game-based learning is suggested.

The rest of the paper is structured as follows: In the next section, the strategy of conducting the review of the literature is elaborated. The previous works on the design of educational games are summarized in the third section. The findings extracted from the examination of the literature are suggested in the fourth section. The discussion upon the finding and the proposed strategies on the effectiveness of graphic design on educational games for kids' learning are suggested in the next section. In the final section, the paper is concluded. Designing the education games must have a certain qualification to evaluate if an education game is good for children or not. An important thing is a graphic design; it is essential because children are more interested in playing the game with good graphic.

\section{METHOD}

The review of the literature was conducted according to the Systematic Literature Review framework [5]. The review was done systematically over a pool of 200 articles in two prominent educational journals within the period of 2013-2017. The journals are the British Journal of Educational Technology and Journal of Computer Assisted Learning. The distribution of the papers reviewed and the relevant papers are depicted in Figure 1.
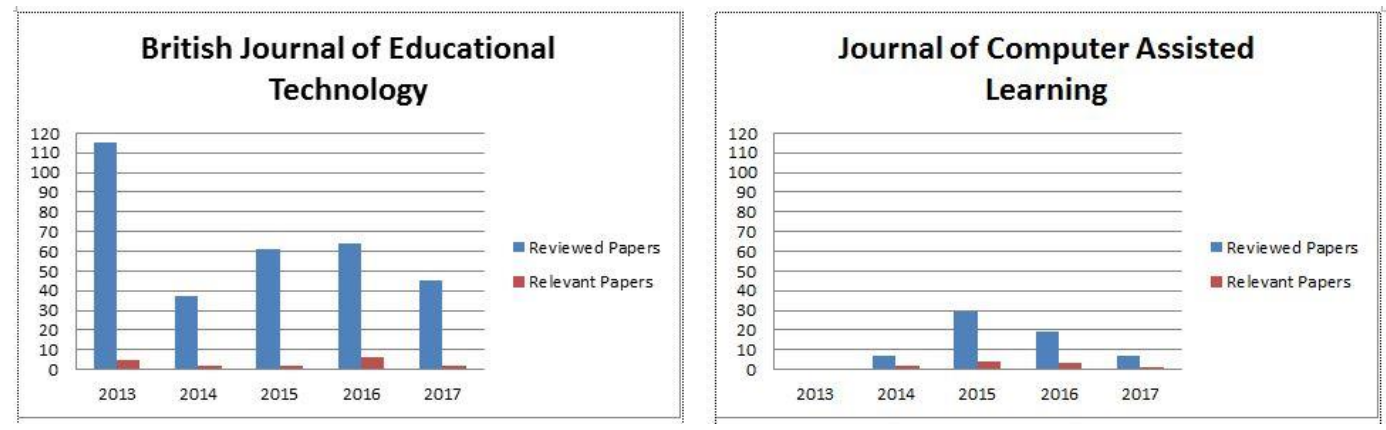

Figure 1 Articles Published by Year

The search was conducted under the following keywords: 'game-based learning,' 'game visual design,' and 'visual learning.' The search carried out under those keywords obtained a total of 25 relevant articles. A concept matrix was developed to identify the insight ascribed to each paper. Two main ideas contained in the reviewed papers are 
learning with the educational game and design graphics on the educational game. The ideas constitute $85 \%$ and $15 \%$ of the entire relevant papers accordingly.

This paper taken all those papers published in both journals into consideration. We disregard the research method adopted in individual studies, since we believed that both qualitative and quantitative approaches would contribute to knowledge. The relevancies of the papers with our investigation are the main predictor of the review.

\section{THE IMPORTANCE OF INTERFACE DESIGN}

The visual graphic design is important in games for its influences and inspiration. As it is depicted in Figure 1, the design is part of the knowledge spheres. It is rooted as one of the knowledge spheres of design in Information Systems [6]. The design of symbolic and visual communication which includes traditional graphic design and illustration now characterizes the designs in the computer interface. Designers regard design as a means of communication by enshrining human values and opinions in their designs. The meaning intended by the designers are communicated to an audience and received as intended or as reconstructed by the public.

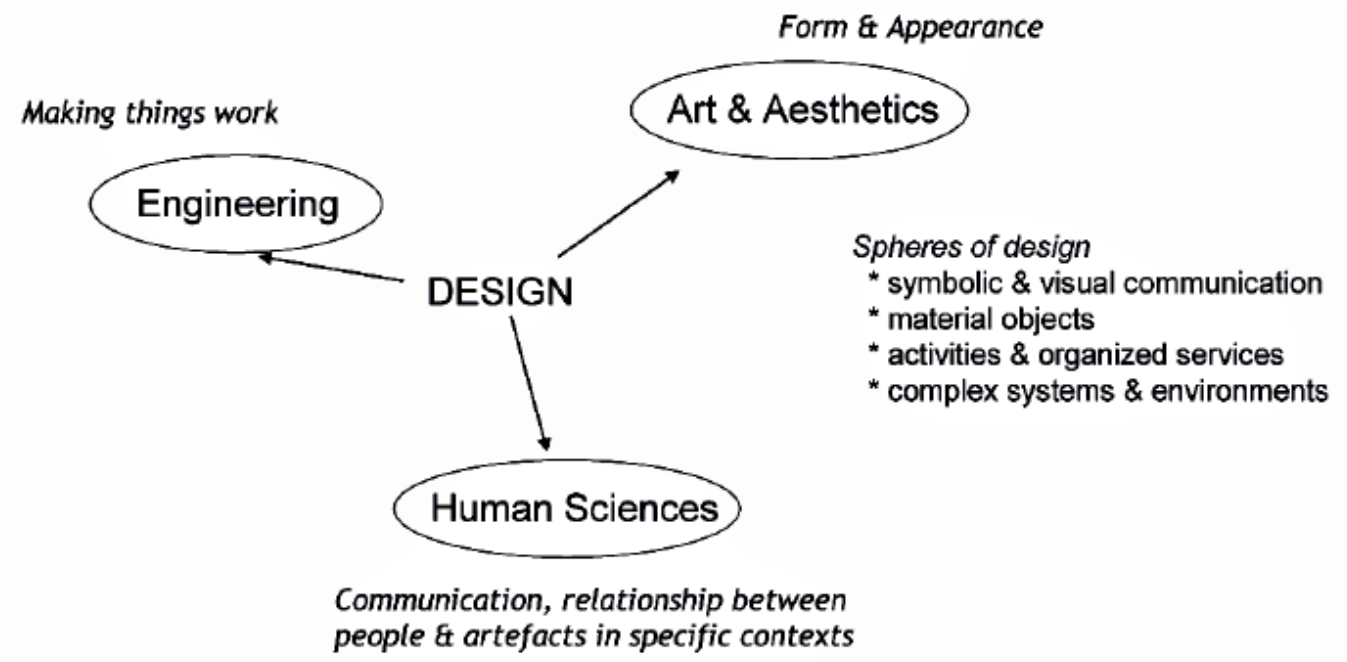

Figure 2. Spheres of design [6]

The notion of design as communication was extended by Redström [7]. He suggested that design is best conceived as the user's experience of an object. In addition to the communicative element of design, the experience that design creates and enables for its recipient audience is as important as the communication element.

For a graphic designer, creativity is required for making the visual imagery [8]. Interface design is important in developing the computer games. Children tend to pay attention to game's interface designs for the first time they play the game. It is potentially motivating and enriches children's imagination through the well-planned layout. Both also the value of visual and audio elements of the game are significant. The sound quality of 
visual, auditory and kinesthetic elements can enhance user's experience while interacting with the game much more [1].

As identified by Soylucicek [1], boring games can be turned into enjoyable games when presented with different designs or contained with the surprising event [9]. The main purpose of developing the graphic design in the educational game is the children's imaginary world can be expanded, enrich their visual world and the information desired to be given can be reinforced at the same time through games they played.

\section{DISCUSSION}

The role of design in the game interface seems to be overlooked by researchers and remotely attractive from practitioner's attention. While game design is undeniably necessary to drive learning into the intended outcome in a new and innovative way [10, 11], the number of papers explicating the importance of interface design in games is surprisingly low. Voluminous explanations, in this regard, remain absent in both journals as it is considered an insignificant theme in the game-based learning discourse. This might result from the search for literature was carried out in improper publication outlets that similar work should be extended to the other journals.

Graphic design in educational games has a significant role for the ability to help to simplify the learning process of students [12]. Although limited numbers of papers explore the role of the game interface, the examination of the literature reveals their function about learners' experience. The elements in the visual include items that can attract students' attention, maintain students' attention during play, react emotionally, minimize the concept of the game to make it easy to understand, facilitate the relations between concepts and elements associated with using flow charts, giving the container to develop students' ideas. The influence of visual elements to learning could be characterised as follows.

\section{Maintaining Student's Attention}

It is evident that interface design attracts learners' attention and guides them through the course of the game. The engagement in learning is demonstrated by the mindfully goaldirected behaviors and reflections that indicate a meaningful and profound involvement in learning activities [13]. The visible progress bar, for example, plays a vital role as the indication of learners' progress toward the end of the game as well as the number of accumulated points or badges of the student [2]. Guided by the bar, in this regard, learners tend to focus on the goal achievement, thus encouraging students to continue the level of the game.

\section{Delivering the amusement in gaming}

The graphical features of the game determine the extent of learner's engagement during the play. The art design and rich auditory output influence the excitement of the participants [2] The representation of the world in the game determines learners' 
association of the game is a fun environment. The profiles of the cartoon characters potentially amusing, for example, children learners.

\section{Visualizing learner's imagination}

The game interface is perceived to contribute to visualize learner's cognitive perception [14]. It helps to organize and perceive information by the use of geometric shapes. Despite research reported insignificant differences of cognitive influences between $2 \mathrm{D}$ and $3 \mathrm{D}$ game design. However, learners valued multi-dimensional learning environment rather than regular delivery of the material [15]. The lesson will be easily understood by the students and even improve the creativity of their imagination.

\section{Simplifies the delivery of complex concepts}

A modified video game was considered effective in conveying knowledge [16]. In the same vein, display-based delivery was achieved similar success. Display items were almost continuously on screen and served a major role in the game by helping players navigate and understand their moves.

The functions of graphic game interfaces distilled from the literature serve the purpose of the educational game in improving teaching and learning. Also, a fun graphic design would likely play a vital role in conveying the intent or essence of a particular lesson according to the age of the student.

\section{CONCLUSION}

This paper presents the knowledge extracted from several papers in the targeted journals. Various researches over the last six years discussed the benefits of games for learning. The reviewed articles are mainly discussing the benefits from game-based learning from the circumstances of their graphics display. Those including the improvement in the effectiveness of learning and students' ability to understand the instruction. While the number of papers available in line with the review's topic is the limitation of this study, an extended study is required to provide a further glance into a wider horizon.

\section{REFERENCES}

[1] Soylucicek, S., Graphic Design on Educational Computer Games. Procedia - Social and Behavioral Sciences, 2012. 46: p. 2083-2087.

[2] Ke, F. and T. Abras, Games for engaged learning of middle school children with special learning needs. British Journal of Educational Technology, 2013. 44(2): p. 225-242.

[3] Simkova, M., Using of Computer Games in Supporting Education. Procedia - Social and Behavioral Sciences, 2014. 141: p. 1224-1227. 
[4] Watson, W. and S. Yang, Games in Schools: Teachers' Perceptions of Barriers to Game-based Learning. Journal of Interactive Leaning Research, 2016. 27(2): p. 17.

[5] Okoli, C. and K. Schabram, A Guide to Conducting a Systematic Literature Review of Information Systems Research. Sprouts Working Papers on Informations Systems, 2010. 10(26): p. 49.

[6] McKay, J., P. Marshall, and G. Heath, An exploration of the concept of design in information systems in Information Systems Foundations: The Role of Design Science, D.N. Hart and S. Gregor, Editors. 2010, ANU Press: Australia.

[7] Redström, J., Towards user design? On the shift from object to user as the subject of design. Design Studies, 2006. 27(2): p. 123-139.

[8] Laing, S. and M. Masoodian, A study of the influence of visual imagery on graphic design ideation. Design Studies, 2016. 45: p. 187-209.

[9] van der Spek, E.D., H. van Oostendorp, and J.-J. Ch. Meyer, Introducing surprising events can stimulate deep learning in a serious game. British Journal of Educational Technology, 2013. 44(1): p. 156-169.

[10] Robson, K., et al., Is it all game? Understanding the principles of gamification. Business Horizons, 2015. 58(4): p. 411-420.

[11] Robson, K., et al., Game on: Engaging customers and employees through gamification. Business Horizons, 2016. 59(1): p. 29-36.

[12] Soyluçiçek, S., Graphical design issues on educational computer games for children. Procedia Social and Behavioral Sciences, 2011. 15: p. 642-645.

[13] Ke, F., K. Xie, and Y. Xie, Game-based learning engagement: A theory- and data-driven exploration. British Journal of Educational Technology, 2016. 47(6): p. 1183-1201.

[14] Allsop, Y., A reflective study into children's cognition when making computer games. British Journal of Educational Technology, 2016. 47(4): p. 665-679.

[15] Ak, O. and B. Kutlu, Comparing $2 D$ and $3 D$ game-based learning environments in terms of learning gains and student perceptions. British Journal of Educational Technology, 2017. 48(1): p. $129-144$.

[16] Moshirnia, A. and M. Israel, The Educational Efficacy of Distinct Information Delivery Systems in Modified Video Games. Journal of Interactive Leaning Research, 2010. 21(3): p. 12.

[17] Weppel, S., M. Bishop, and H. Munoz-avila, The Design of Scaffolding in Game-based Learning: A Formative Evaluation. Journal of Interactive Leaning Research, 2012. 23(4): p. 31.

[18] Siyahhan, S., S. Barab, and C. James, Youth and the Ethics of Identity Play in Virtual Spaces. Journal of Interactive Leaning Research, 2011. 22(1): p. 27.

[19] Siko, J. and M. Barbour, Design Research Using Game Design as an Instructional Strategy. Journal of Interactive Leaning Research, 2014. 25(3): p. 21.

[20] Ritzhaupt, A., H. Higgins, and B. Allred, Effects of modern educational game play on attitudes towards mathematics, mathematics self-efficacy, and mathematics achievement. Journal of Interactive Leaning Research, 2011. 22(2): p. 20.

[21] Molnar, A., J. Virseda, and V. Frias-MArtinez, Insights from EducaMovil: Involving Teachers in Creating Educational Content for Mobile Learning Games. Journal of Interactive Leaning Research, 2015. 26(2): p. 22.

[22] Ketamo, H. and M. Suominen, Learning-by-Teaching in Educational Game: Educational Outcome, User Experience, and Social Networks. Journal of Interactive Leaning Research, 2010. 21(2): p. 18.

[23] Epley, J., Learning by Doing: Using an Online Simulation Game in an International Relations Course. Journal of Interactive Leaning Research, 2016. 27(3): p. 17.

[24] Bluemink, J. and S. Järvelä, Elements of collaborative discussion and shared problem solving in a voice-enhanced multiplayer game. Journal of Interactive Leaning Research, 2011. 22(1): p. 27.

[25] Tsai, C.-W. and Y.-T. Fan, Research trends in game-based learning research in online learning environments: A review of studies published in SSCI-indexed journals from 2003 to 2012. British Journal of Educational Technology, 2013. 44(5): p. E115-E119. 
[26] Reese, D.D., B.G. Tabachnick, and R.E. Kosko, Video game learning dynamics: Actionable measures of multidimensional learning trajectories. British Journal of Educational Technology, 2015. 46(1): p. 98-122.

[27] Li, Z.-Z., Y.-B. Cheng, and C.-C. Liu, A constructionism framework for designing game-like learning systems: Its effect on different learners. British Journal of Educational Technology, 2013. 44(2): p. 208-224.

[28] Iten, N. and D. Petko, Learning with serious games: Is fun playing the game a predictor of learning success? British Journal of Educational Technology, 2016. 47(1): p. 151-163.

[29] Hess, T. and G. Gunter, Serious game-based and nongame-based online courses: Learning experiences and outcomes. British Journal of Educational Technology, 2013. 44(3): p. 372-385.

[30] Feng, C.-Y. and M.-P. Chen, The effects of goal specificity and scaffolding on programming performance and self-regulation in game design. British Journal of Educational Technology, 2014. 45(2): p. 285-302.

[31] Cheng, M.-T., et al., An educational game for learning human immunology: What do students learn and how do they perceive? British Journal of Educational Technology, 2014. 45(5): p. 820833.

[32] Chen, C.-H., G.-Z. Liu, and G.-J. Hwang, Interaction between gaming and multistage guiding strategies on students' field trip mobile learning performance and motivation. British Journal of Educational Technology, 2016. 47(6): p. 1032-1050.

[33] Calvo-Ferrer, J.R., Educational games as stand-alone learning tools and their motivational effect on L2 vocabulary acquisition and perceived learning gains. British Journal of Educational Technology, 2017. 48(2): p. 264-278.

[34] Bakker, M., M. Van den Heuvel-Panhuizen, and A. Robitzsch, Longitudinal data on the effectiveness of mathematics mini-games in primary education. British Journal of Educational Technology, 2015. 46(5): p. 999-1004. 


\section{Appendix}

The papers reviewed in the investigation.

\begin{tabular}{|c|c|c|c|}
\hline No & Title & Author(s) & \\
\hline 1 & $\begin{array}{l}\text { The Design of Scaffolding in } \\
\text { Game-based Learning: A Formative } \\
\text { Evaluation }\end{array}$ & $\begin{array}{l}\text { Weppel, Bishop } \\
{[17]}\end{array}$ & $\begin{array}{l}\text { Journal } \\
\text { Interactive } \\
\text { Research }\end{array}$ \\
\hline 2 & \begin{tabular}{l}
\multicolumn{1}{c}{ Games in Schools: } \\
Teachers' \\
Barriers \\
Learning
\end{tabular} & $\begin{array}{l}\text { Watson and Yang } \\
\text { [4] }\end{array}$ & $\begin{array}{l}\text { Journal } \\
\text { Interactive } \\
\text { Research }\end{array}$ \\
\hline 3 & $\begin{array}{l}\text { Youth and the Ethics of Identity } \\
\text { Play in Virtual Spaces. }\end{array}$ & $\begin{array}{l}\text { Siyahhan, Barab } \\
\text { [18] }\end{array}$ & $\begin{array}{l}\text { Journal } \\
\text { Interactive } \\
\text { Research }\end{array}$ \\
\hline 4 & $\begin{array}{l}\text { Design Research Using Game } \\
\text { Design as an Instructional Strategy. }\end{array}$ & $\begin{array}{l}\text { Siko and Barbour } \\
\text { [19] }\end{array}$ & $\begin{array}{l}\text { Journal } \\
\text { Interactive } \\
\text { Research }\end{array}$ \\
\hline 5 & $\begin{array}{l}\text { Effects of modern educational } \\
\text { game play on attitudes towards } \\
\text { mathematics, mathematics self- } \\
\text { efficacy, and mathematics } \\
\text { achievement. }\end{array}$ & $\begin{array}{l}\text { Ritzhaupt, Higgins } \\
\text { [20] }\end{array}$ & $\begin{array}{l}\text { Journal } \\
\text { Interactive } \\
\text { Research }\end{array}$ \\
\hline 6 & $\begin{array}{l}\text { The Educational Efficacy of } \\
\text { Distinct Information Delivery } \\
\text { Systems in Modified Video Games. }\end{array}$ & $\begin{array}{l}\text { Moshirnia } \\
\text { Israel [16] }\end{array}$ & $\begin{array}{l}\text { Journal } \\
\text { Interactive } \\
\text { Research }\end{array}$ \\
\hline 7 & \begin{tabular}{l}
\multicolumn{1}{c}{ Insights from EducaMovil: } \\
Involving Teachers in Creating \\
Educational Content for Mobile \\
Learning Games.
\end{tabular} & $\begin{array}{l}\text { Molnar, Virseda } \\
\text { [21] }\end{array}$ & $\begin{array}{l}\text { Journal } \\
\text { Interactive } \\
\text { Research }\end{array}$ \\
\hline 8 & $\begin{array}{l}\text { Learning-by-Teaching in } \\
\text { Educational Game: Educational } \\
\text { Outcome, User Experience, and } \\
\text { Social Networks. }\end{array}$ & $\begin{array}{ll}\text { Ketamo } & \text { and } \\
\text { Suominen [22] } & \end{array}$ & $\begin{array}{l}\text { Journal } \\
\text { Interactive } \\
\text { Research }\end{array}$ \\
\hline 9 & $\begin{array}{l}\text { Learning by Doing: Using an } \\
\text { Online Simulation Game in an } \\
\text { International Relations Course. }\end{array}$ & Eple & $\begin{array}{l}\text { Journal } \\
\text { Interactive } \\
\text { Research } \\
\end{array}$ \\
\hline 0 & $\begin{array}{l}\text { Elements of collaborative } \\
\text { discussion and shared problem } \\
\text { solving in a voice-enhanced } \\
\text { multiplayer game. }\end{array}$ & $\begin{array}{l}\text { Bluemink } \\
\text { Järvelä [24] }\end{array}$ & $\begin{array}{l}\text { Journal } \\
\text { Interactive } \\
\text { Research }\end{array}$ \\
\hline 1 & $\begin{array}{l}\text { Introducing surprising events } \\
\text { can stimulate deep learning in a } \\
\text { serious game. }\end{array}$ & $\begin{array}{l}\text { van der Spek, van } \\
\text { Oostendorp [9] }\end{array}$ & $\begin{array}{l}\text { British Journal of } \\
\text { Education Technology }\end{array}$ \\
\hline 2 & $\begin{array}{l}\text { Research trends in game-based } \\
\text { learning research in online learning } \\
\text { environments: A review of studies } \\
\text { published in } \mathrm{SSCl} \text {-indexed journals } \\
\text { from } 2003 \text { to } 2012 \text {. }\end{array}$ & Tsa & $\begin{array}{l}\text { British Journal of } \\
\text { Education Technology }\end{array}$ \\
\hline
\end{tabular}




\begin{tabular}{|c|c|c|c|c|}
\hline 3 & 1 & \begin{tabular}{l}
\multicolumn{2}{c}{ Video game learning dynamics: } \\
Actionable measures of \\
multidimensional \\
trajectories.
\end{tabular} & $\begin{array}{l}\text { Reese, Tabachnick } \\
\text { [26] }\end{array}$ & $\begin{array}{l}\text { British Journal of } \\
\text { Education Technology }\end{array}$ \\
\hline 4 & 1 & $\begin{array}{l}\text { A constructionism framework } \\
\text { for designing game-like learning } \\
\text { systems: Its effect on different } \\
\text { learners. }\end{array}$ & Li, Cheng [27] & $\begin{array}{l}\text { British Journal of } \\
\text { Education Technology }\end{array}$ \\
\hline 5 & 1 & $\begin{array}{l}\text { Games for engaged learning of } \\
\text { middle school children with special } \\
\text { learning needs. }\end{array}$ & Ke and Abras [2] & $\begin{array}{l}\text { British Journal of } \\
\text { Education Technology }\end{array}$ \\
\hline 6 & 1 & $\begin{array}{l}\text { Game-based learning } \\
\text { engagement: A theory- and data- } \\
\text { driven exploration. }\end{array}$ & Ke, Xie [13] & $\begin{array}{l}\text { British Journal of } \\
\text { Education Technology }\end{array}$ \\
\hline 7 & 1 & $\begin{array}{l}\text { Learning with serious games: Is } \\
\text { fun playing the game a predictor of } \\
\text { learning success?. }\end{array}$ & Iten and Petko [28] & $\begin{array}{l}\text { British Journal of } \\
\text { Education Technology }\end{array}$ \\
\hline 8 & 1 & $\begin{array}{l}\text { Serious game-based and } \\
\text { nongame-based online courses: } \\
\text { Learning experiences and outcomes. }\end{array}$ & $\begin{array}{l}\text { Hess and Gunter } \\
\text { [29] }\end{array}$ & $\begin{array}{l}\text { British Journal of } \\
\text { Education Technology }\end{array}$ \\
\hline 9 & 1 & $\begin{array}{l}\text { The effects of goal specificity } \\
\text { and scaffolding on programming } \\
\text { performance and self-regulation in } \\
\text { game design. }\end{array}$ & Feng and Chen [30] & $\begin{array}{r}\text { British Joul } \\
\text { Education Tech }\end{array}$ \\
\hline 0 & 2 & $\begin{array}{l}\text { An educational game for } \\
\text { learning human immunology: What } \\
\text { do students learn and how do they } \\
\text { perceive? }\end{array}$ & Cheng, Su [31] & $\begin{array}{l}\text { British Journal of } \\
\text { Education Technology }\end{array}$ \\
\hline 1 & 2 & \begin{tabular}{l}
\multicolumn{1}{c}{ Interaction between gaming } \\
and multistage guiding strategies \\
on students' field trip mobile \\
learning performance \\
motivation
\end{tabular} & Chen, Liu [32] & $\begin{array}{l}\text { British Journal of } \\
\text { Education Technology }\end{array}$ \\
\hline 2 & 2 & $\begin{array}{l}\text { Educational games as stand- } \\
\text { alone learning tools and their } \\
\text { motivational effect on } L 2 \text { vocabulary } \\
\text { acquisition and perceived learning } \\
\text { gains. }\end{array}$ & $\mathrm{Cal}$ & $\begin{array}{l}\text { British Journal of } \\
\text { Education Technology }\end{array}$ \\
\hline 3 & 2 & $\begin{array}{l}\text { Longitudinal data on the } \\
\text { effectiveness of mathematics mini- } \\
\text { games in primary education. }\end{array}$ & $\begin{array}{l}\text { Bakker, Van den } \\
\text { Heuvel-Panhuizen } \\
{[34]}\end{array}$ & $\begin{array}{l}\text { British Journal of } \\
\text { Education Technology }\end{array}$ \\
\hline 4 & 2 & $\begin{array}{l}\text { A reflective study into children's } \\
\text { cognition when making computer } \\
\text { games. }\end{array}$ & Allsop [14] & $\begin{array}{l}\text { British Journal of } \\
\text { Education Technology }\end{array}$ \\
\hline 5 & 2 & $\begin{array}{l}\text { Comparing } 2 \mathrm{D} \text { and } 3 \mathrm{D} \text { game- } \\
\text { based learning environments in } \\
\text { terms of learning gains and student } \\
\text { perceptions. }\end{array}$ & Ak and Kutlu [15] & $\begin{array}{l}\text { British Journal of } \\
\text { Education Technology }\end{array}$ \\
\hline
\end{tabular}

